\title{
Ecological Diversity of Pteridophytes Across Land Use Types in Mt. Makiling Forest Reserve, Luzon Island, Philippines
}

\author{
Marjorie D. delos Angeles (corresponding \\ author) \\ Plant Biology Division, Institute of Biological Sciences, College of \\ Arts and Sciences, University of the Philippines Los Baños, \\ Laguna, Philippines \\ mddelosangelesı@up.edu.ph
}

\section{Inocencio E. Buot, Jr.}

Plant Biology Division, Institute of Biological Sciences, College of Arts and Sciences, University of the Philippines Los Baños,

Laguna, Philippines

\author{
Ailene A. Alcala \\ Plant Biology Division, Institute of Biological Sciences, College of \\ Arts and Sciences, University of the Philippines Los Baños, \\ Laguna, Philippines
}

Publication Information:

Received 10 August 2020, Accepted 25 November 2020, Available online 22 December 2020

DOI: 10.21463/jmic.2020.09.2.08

\begin{abstract}
Changes are evident in fern species richness, composition, and abundance as a result of environmental changes caused by forest conversion to various land use types. This study identified fern species and described its distribution pattern with reference to ecological parameters obtained from various land use types across the northeastern slope of Mt. Makiling Forest Reserve, Los Baños, Philippines. The plot technique was employed using a 20x20 meter quadrat. Three $5 \times 2$ subquadrats were randomly distributed within the established quadrat. Cluster and ordination analysis were used and edaphic factors were analyzed. Fern specimens were identified (sensu PPG) and measured. Samples were collected for herbarium vouchers and were deposited at the Plant Biology Division Herbarium, University of the Philippines Los Baños (PBDH). Cluster analysis revealed six land use types: buffer, agroforest, agri-farm, roadside, mahogany, and forest. Twenty-nine (29) fern species belonging to 23 genera from 14 families were recorded across the different land use types. Among the land use types, the forest had the highest fern species richness (13) and the agri-farm and Mahogany had the least (6). Canonical correspondence analysis indicated that moisture, $\mathrm{OM}, \mathrm{pH}$, and $\mathrm{CEC}$ were significant explanatory
\end{abstract}


drivers of fern distribution especially in the Mahogany and Agroforest land use type. Understanding the fern community patterns and edaphic factors in Mt. Makiling would aid in its conservation planning.

\section{Keywords}

Land use types, ferns, Mt. Makiling Forest Reserve

\section{Introduction}

The Island of Luzon is the largest composite island in the Philippines. It is comprised of 8 administrative regions and 30 provinces, one of which is the province of Laguna. Among many others, Laguna is known for its mystic and majestic solitary mountains, Mt. Banahaw and Mt. Makiling. Mt. Makiling Forest Reserve (MMFR) is a tropical rainforest known for its floral and faunal biodiversity. It was established in 1910 and covers $80 \%$ of Mt. Makiling's land area. It was recorded to have native and exotic species classified into 225 families, 949 genera, 2,038 species and 19 subspecies of flowering plants and ferns (Pancho 1983I LLDA 2005). The species diversity in the reserve may be attributed to the landform and its location as well as the 1,109 meters rise of the mountain that offers plenty of niches as it is subject to drastic changes in altitude, climate, and soil. There are four types of vegetation recognized in the mountain based on altitude: upper montane rain forest (>1000 m.a.s.l.), lower montane forest (>750 m.a.s.I.), lowland evergreen forest (100-500 m.a.s.l.), and parang vegetation (< 100 m.a.s.I.) (Fernando et al., 2004).

Mt. Makiling is considered as an important biological area due to its scientific history and peculiarities of its flora and fauna (Pancho, 1983). However, it is not exempted from the continuous threats by the expanding human settlements, agricultural croplands, and urban and industrial zones (Bantayan, 2001). In spite of the policies to reduce illegal logging and agricultural expansion, these land use change processes still pose as threats to the remaining forest areas in the country (Verburg et al., 2006). Mt. Makiling is prone to disturbances since it is open and appeals to visitors, students, and researchers alike. Due to this continuous disturbance, conservation measures should be designed to aid in the preservation of various vulnerable species such as pteridophytes or the ferns.

Pteridophytes are one of the many plant groups in Mt. Makiling Forest Reserve (MMFR). Several fern species are food plants, medicinals, and ornamentals. They could be very good ecological indicators of disturbances across land use types due to their heightened sensitivity to these alterations. They are excellent biological tools in recognizing differences in climatic factors such as temperature, humidity, and elevation (Banaticla and Buot, 2004, 2005; delos Angeles and Buot, 2012). In addition, they are susceptible to edaphic changes such as pH (delos Angeles and Buot, 2015), moisture, and even heavy metals from contaminated soils (Claveria et al., 2019). There is a need therefore to document the fern population, especially, across land use types (Mahogany, Agri-farm, Buffer, Agro-forest, Roadside, \& Forest) of Mt. Makiling so that, patterns will be established leading to the formulation of management strategy on fern conservation in Mt. Makiling.

Generally, this study was conducted to document ferns species recorded across different land use types on Mt. Makiling. Specifically, this study aimed to:

1. Document the fern species found in various land use types such as Mahogany, Agri-farm, Buffer, Agro-forest, Roadside, \& Forest and; 
2. Describe the pattern of fern distribution with reference to land use types and ecological parameters using multivariate tools.

\section{Materials and Methodology}

\section{Study Area}

The study was conducted in Mt. Makiling, Los Baños, Laguna (Figure 1). The sampling sites were located at an altitude range of 150-950 m.a.sl. across the northeastern side of the mountain. Six (6) different land use types were recognized and identified: i) Mahogany, ii) Agri-farm, iii) Buffer, iv) Agro-forest, v) Roadside, and vi) Forest. Mahogany land use type refers to area dominated by Swietenia macrophylla. Agri-farm land use type on the other hand refers to areas with clearings devoted to the cultivation of economically important crops and raising of livestock. The buffer land use type refers to a forested area which lies in between the forest edge and the undisturbed forest. The Agro-forest land use type refers to the area of the mountain where trees and shrubs are grown in association with economically important crops. The Roadside land use type refers to vegetated area beside a road. Forest land use type on the other hand refers to the intact forest of the mountain.
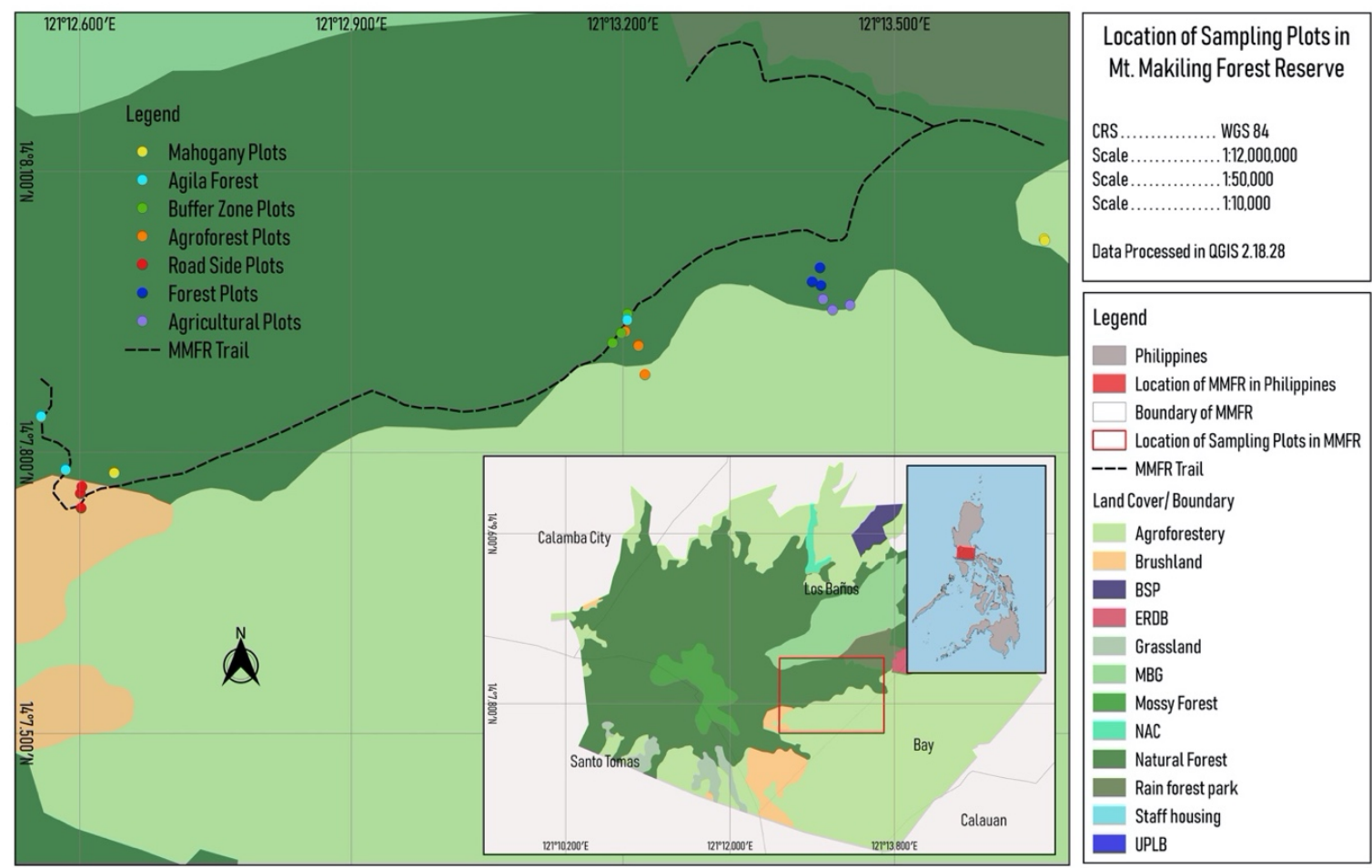

Fig 1. The study area showing the identified land use types found across the northeastern slope of the mountain. The Philippine map (inset) shows the location of Mt. Makiling. 
In documenting fern species found along the mountain, the plot technique was employed using a $10 \times 10$ meter quadrat established within the identified land use type. Within the quadrat, three (3) $5 \times 2$ subquadrats were randomly distributed within the established quadrat. In each quadrat, all the occurring pteridophyte species were taken into account. The aboveground ramet density was considered to quantify density and abundance. At each station, the following data were obtained: (a) species name, (b) total cover, and (c) frequency. The dominating plant species in the area were determined by obtaining the following parameters: relative cover $(\mathrm{RC})$ and relative frequency $(\mathrm{RF})$. These parameters were then utilized to compute for the Importance Values (IV) using the formula adapted from Mueller-Dombois and Ellenberg (1974):

$$
\begin{gathered}
\text { Frequency }=\frac{\text { No.ofindividualsofaspecies }}{\text { TotalArea }} \times 100 \\
\text { RelativeFrequency }=\frac{\text { Frequencyvalueforaspecies }}{\text { Totaloffrequencyvaluesforallspp. }} \times 100 \\
I V=\frac{\text { RelativeCover }+ \text { RelativeFrequency }}{2}
\end{gathered}
$$

Shannon index of diversity was also computed with the following formula. Shannon Index of diversity $(H)$ :

$$
H=-\sum\left(p_{i} \ln p_{i}\right)
$$

Where $p_{i}=$ relative abundance or the proportion of total sample belonging to nth species.

\section{Fern collection}

All fern species found in the plots found in various land use types were considered, whether growing on soils (mesophytic), rocks (lithophytic) or on tree trunks or branches (epiphytic). The epiphytic class included ferns found growing on fallen trees and branches, as well as those growing on standing trees, provided that they do not have a root connection to the ground (Jones et al., 2006). Three (3) individuals for each fern species were collected. The unknown species were identified based on the collection of herbarium specimens at the Plant Biology Division Herbarium (PBDH), Plant Systematics Laboratory, Institute of Biological Sciences, College of Arts and Sciences, University of the Philippines Los Baños and from the Philippine National Herbarium, National Museum in Manila. Fern specialists were consulted for the identification of the collected unknown specimens. PBDH herbarium collections, Mike Price's "The Pteridophytes of Mt. Makiling and Vicinity" were also used as reference materials in identifying the plant specimens. Available online resources such as “Co's Digital Flora of the Philippines" (Pelser et al. 2011) were also consulted. Taxonomic information regarding the plant samples were verified from references authored by Moody et al. (1984). On-line data bases were consulted. Characterization of fern species were done in the Plant Systematics Laboratory, Plant Biology Division, IBS, UPLB.

\section{Data analyses}

Altitude and geographic location were measured using a geographic positioning system (GPS) device. Abiotic data were collected such as ph, OM, N, P, K, CEC, and soil moisture. In order to detect significant changes in the floristic 
composition among fern communities recorded across different land use types a similarity analysis (ANOSIM) was run which performed 999 randomized permutations on data to calculate the statistic $\mathrm{R}$ global with their corresponding probability $\mathrm{p}$ (Clarke and Gorley, 2006). The quantitative data obtained from the water, soil and plant analysis were subjected to to Canonical Correspondence Analysis (CCA). The researchers performed principal coordinate analysis (PCoA) of Bray-Curtis similarity of fern species abundance data among different land use types where square root transformed and abiotic factors were used without further transformation (ph, OM, N, P, K, CEC, and soil moisture). To detect significant differences in the fern floristic composition across different land use types a similarity index (ANOSIM) was used. All analyses were performed using the Paleontological Statistics Software Package Version 3.25 (2019).

\section{Results and Discussion}

\section{Fern species composition}

A total of 29 fern species belonging to 23 genera from 14 families were recorded across 18 plots from various land use types. The families with greatest species richness were recorded Thelypteridaceae (5), Polypodiaceae (3), Dryopteridaceae (3), and Pteridaceae (3). The most diverse genus were Asplenium, Sphaerostephanos, Bolbitis, and Phymatosorus with two species each (Table 1).

Species richness and abundance differed across different land use types. Species richness was observably highest in the Forest land use types which resulted to a total of thirteen (13) fern species (Table 2). This may be attributed to the diversity of trees in the forests providing a microclimate that is favorable for growth and development for a number of fern species. According to Kluge et al. (2006), fern species richness has often been related to higher humidity and moderate temperature. Similarly, in a study conducted by Abotsi et al. (2020), pteridophyte species diversity and distribution in Togo, West Africa were highly influenced by climatic variables, humidity-related variables, insolation, and human disturbances. Based from Table 3, the forest land use type was analyzed to have the highest Shannon values among the different land use types $\left(\mathrm{H}^{\prime}=2.05\right)$. A variety of substrates including but not limited to soil, rocks, barks, and branches allows terrestrial, lithophytic, epiphytic, and epilithic fern species to grow.

The Lowest species richness is from the Mahogany and Agri-farm land use types with a total number of six (6) recorded fern species. Low species richness in the Agri-farm land use type may be attributed to frequent tillage and disturbances of the soil as a result of agricultural practices. The Mahogany land use type is a monoculture plantation dominated by the exotic tree species Swietenia macrophylla King. Based on a study conducted by Mukaromah, Purwstri and Fiju (2016), Mahogany leaf litters were recorded to have a strong allelopathic potential in plant-plant interactions wherein increasing concentration of mahogany leaf litter resulted to inhibition of radicle lettuce seedling growth. The allelopathic nature of mahogany leaf litter may have likewise inhibited the growth of fern species resulting to a low species richness. Moreover, the Mahogany land use type was also computed to have the lowest Shannon value $\left(H^{\prime}=0.94\right)$. High relative frequency (RF) and relative cover (RC) in the Agrifarm land use type may be attributed to more open areas for fern growth and reproduction (Figure 2). Based from the analyzed data, the more disturbed a land use type is the lower is the fern diversity. 
Table 1. Recorded fern species found across land use types found along the northeastern slope Mt. Makiling Forest Reserve (MMFR). Nomenclature based on the Pteridophyte Phylogeny Group (2016).

\begin{tabular}{|c|c|c|c|c|c|}
\hline Class & Order & Family & Scientific Name & $\begin{array}{l}\text { Status of Species } \\
\text { Names }\end{array}$ & Exsiccata \\
\hline \multirow[t]{2}{*}{ Lycopodiopsida } & \multirow[t]{2}{*}{ Lycopodiales } & \multirow[t]{2}{*}{ Selaginellaceae } & Selaginella sp. 1 & - & - \\
\hline & & & Selaginella cupressina (Willd.) Spring & Accepted & $\begin{array}{l}\text { delos Angeles } 6896 \\
\text { (PBDH) }\end{array}$ \\
\hline \multirow[t]{26}{*}{ Polypodiopsida } & Marattiidiales & Marattiaceae & Angiopteris evecta & Accepted & $\begin{array}{l}\text { delos Angeles } 6897 \\
\text { (PBDH) }\end{array}$ \\
\hline & Schizaeales & Lygodiaceae & Lygodium circinatum (Burm. F.) Sw. & Accepted & $\begin{array}{l}\text { delos Angeles 6898-6900 } \\
\text { (PBDH) }\end{array}$ \\
\hline & Lindsaeineae & Lindsaeaceae & Lindsaea fissa Copel. & Accepted & - \\
\hline & \multirow[t]{3}{*}{ Pteridinae } & \multirow[t]{3}{*}{ Pteridaceae } & Adiantum diaphanum Blume & Accepted & $\begin{array}{l}\text { delos Angeles 6902-6904 } \\
\text { (PBDH) }\end{array}$ \\
\hline & & & Pteris blumeana C. Agardh & Accepted & - \\
\hline & & & Pteris longipinnula Wall. Ex J. Agardh & Accepted & $\begin{array}{l}\text { delos Angeles 6908-6909 } \\
\text { (PBDH) }\end{array}$ \\
\hline & \multirow[t]{2}{*}{ Dennstaedtiinae } & \multirow[t]{2}{*}{ Dennstaedtiaceae } & Dennstaedtia philippinensis Copel. & Unresolved & - \\
\hline & & & Microlepia sp. & - & $\begin{array}{l}\text { delos Angeles } 6910 \\
\text { (PBDH) }\end{array}$ \\
\hline & \multirow{8}{*}{$\begin{array}{l}\text { Aspleniinae } \\
\text { (Eupolypods II) }\end{array}$} & \multirow[t]{2}{*}{ Aspleniacae } & Asplenium sp. & - & - \\
\hline & & & Asplenium tenerum G. Forst. & Accepted & $\begin{array}{l}\text { delos Angeles 6911-6913 } \\
\text { (PBDH) }\end{array}$ \\
\hline & & \multirow[t]{5}{*}{ Thelypteridaceae } & $\begin{array}{l}\text { Cyclosorus terminans (J. Sm. Ex Hook.) } \\
\text { K.H. Shing }\end{array}$ & Accepted & $\begin{array}{l}\text { delos Angeles } 6915 \\
\text { (PBDH) }\end{array}$ \\
\hline & & & Christella sp. & - & - \\
\hline & & & Pneumatopteris nitidula & Unresolved & - \\
\hline & & & Sphaerostephanos hirsutus Holttum & Unresolved & $\begin{array}{l}\text { delos Angeles 6916-6917 } \\
\text { (PBDH) }\end{array}$ \\
\hline & & & Sphaerostephanus unitus (L.) Holttum & Accepted & $6918-6920$ \\
\hline & & Athyriaceae & Diplazium esculentum (Retz.) Sw. & Accepted & - \\
\hline & \multirow{10}{*}{$\begin{array}{l}\text { Polypodiinae } \\
\text { (Eupolypods I) }\end{array}$} & \multirow[t]{3}{*}{ Dryopteridaceae } & Bolbitis heteroclita (C. Presl) Ching & Accepted & - \\
\hline & & & Bolbitis sinuata Hennipman & Unresolved & $\begin{array}{l}\text { delos Angeles } 6921 \\
\text { (PBDH) }\end{array}$ \\
\hline & & & Pleocnemia macrodonta Holttum & Unresolved & $\begin{array}{l}\text { delos Angeles 6922-6931 } \\
\text { (PBDH) }\end{array}$ \\
\hline & & Nephrolepidaceae & Nephrolepis cordifolia (L.) C. Presl & Accepted & $\begin{array}{l}\text { delos Angeles } 6928 \\
\text { (PBDH) }\end{array}$ \\
\hline & & \multirow[t]{2}{*}{ Tectariaceae } & Aspidium crenatus (Cav.) Ching & Accepted & - \\
\hline & & & Tectaria siifolia (Willd.) Copel. & Accepted & $\begin{array}{l}\text { delos Angeles 6929-6931 } \\
\text { (PBDH) }\end{array}$ \\
\hline & & Davalliaceae & $\begin{array}{l}\text { Davallia denticulata (Burm. F.) Mett. Ex } \\
\text { Kuhn }\end{array}$ & Accepted & $\begin{array}{l}\text { delos Angeles } 6932 \\
\text { (PBDH) }\end{array}$ \\
\hline & & \multirow[t]{3}{*}{ Polypodiaceae } & Microsorum longissimum Fee & Unresolved & - \\
\hline & & & $\begin{array}{l}\text { Phymatosorus membranifolium (R. Br.) } \\
\text { S.G. Lu }\end{array}$ & Accepted & $\begin{array}{l}\text { delos Angeles } 6933 \\
\text { (PBDH) }\end{array}$ \\
\hline & & & $\begin{array}{l}\text { Phymatosorus scolopendria (Burm.f.) } \\
\text { Pic. Serm. }\end{array}$ & Accepted & $\begin{array}{l}\text { delos Angeles 6934-6935 } \\
\text { (PBDH) }\end{array}$ \\
\hline
\end{tabular}


Table 2. Frequency of occurrence of ferns across land use types of Mt. Makiling Forest Reserve, Philippines.

\begin{tabular}{|c|c|c|c|c|c|c|}
\hline Fern species & M & A & B & $A F$ & $\mathbf{R}$ & $F$ \\
\hline Adiantum diaphanum & - & + & - & - & - & + \\
\hline Cyclosorus terminans & - & + & - & + & + & - \\
\hline Angiopteris evecta & + & - & + & - & + & + \\
\hline Asplenium sp. & + & - & - & - & - & + \\
\hline Asplenium tenerum & - & - & - & - & - & + \\
\hline Bolbitis heteroclita & - & - & - & - & + & - \\
\hline Bolbitis sinnuata & - & - & + & - & - & + \\
\hline Christella sp. & - & - & - & - & - & + \\
\hline Davallia denticulata (Burm. F.) Mett. Ex Kuhn & + & - & - & + & - & - \\
\hline Dennstaedtia philippinensis & - & - & - & + & - & - \\
\hline Diplazium esculentum & + & - & - & - & - & - \\
\hline Lygodium circinnatum & - & - & - & + & - & - \\
\hline Microlepia sp. & - & - & - & + & - & - \\
\hline Microsorum longissimum & - & - & - & + & - & + \\
\hline Phymatosorus membranifolius & - & - & - & - & + & - \\
\hline Nephrolepis cordifolia (L.) C. Presl & - & - & - & - & - & + \\
\hline Phymatosorus scolopendria (Burm.f.) Pic. Serm. & + & - & - & - & - & + \\
\hline Pleocnemia macrodonta Holttum & - & + & + & + & + & + \\
\hline Pneumatopteris nitidula & - & + & + & + & - & - \\
\hline Pteris blumeana Agardh & - & - & + & - & - & - \\
\hline Pteris longipinnula & + & - & + & - & - & + \\
\hline Selaginella 1 & - & - & + & + & - & + \\
\hline Selaginella cuppressina & - & - & + & - & + & - \\
\hline Sphaerostephanos hirsutus & - & + & - & - & + & - \\
\hline Sphaerostephanus unitus & - & + & - & - & - & - \\
\hline Tectaria crenata & - & - & + & - & - & - \\
\hline Tectaria siifolia & - & - & - & + & + & - \\
\hline Lindsaea fissa Copel. & - & - & - & - & - & + \\
\hline
\end{tabular}

*M-Mahogany, A-Agri-farm, B-Buffer, AF-Agroforest, R-Roadside, \& F-Forest 
Table 3. Calculated Abundance and Shannon index of diversity for the different land use types found in Mt. Makiling Forest Reserve.

\begin{tabular}{|l|l|l|l|}
\hline \multicolumn{1}{|c|}{ Land use type } & \multicolumn{1}{c|}{ Richness } & \multicolumn{1}{c|}{ Abundance } & Shannon index of diversity \\
\hline Agri-farm & 6 & 325 & 1.279299 \\
\hline Agroforest & 10 & 823 & 1.1372534 \\
\hline Buffer & 9 & 264 & 1.6123518 \\
\hline Forest & 13 & 749 & 2.0525906 \\
\hline Mahogany & 6 & 268 & 0.9353229 \\
\hline Roadside & 7 & 325 & 1.7992275 \\
\hline
\end{tabular}
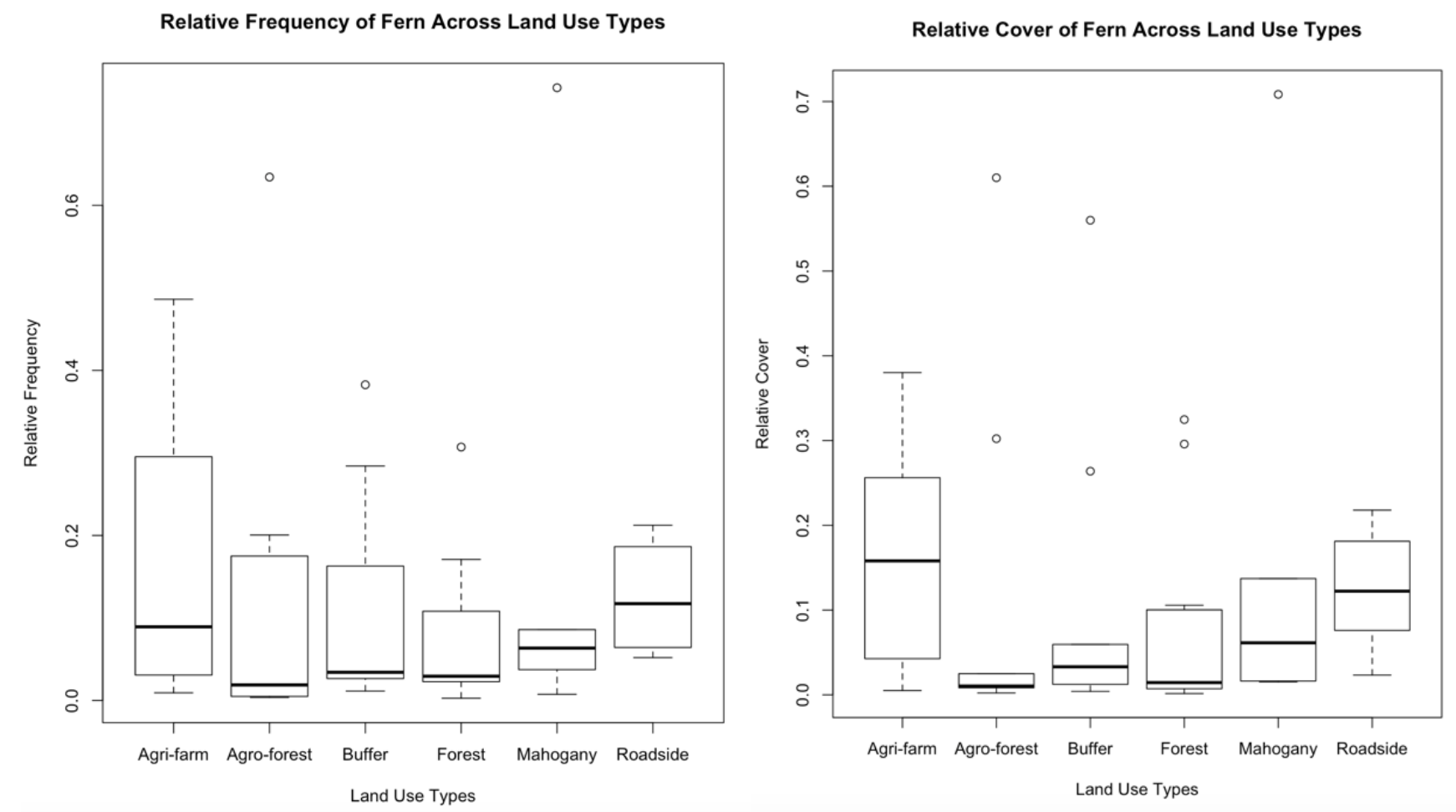

Fig 2. A) Relative frequency and B) Relative cover of fern species recorded across land use types in Mt. Makiling Forest Reserve, Laguna, Philippines.

\section{Land Use Types}

The total fern density values of each fern species recorded from the 18 plots across different land use types in Mt. Makiling were subjected to cluster analysis using Euclidean distance. At a dissimilarity level of 3.75, a dendrogram (Figure 3) was constructed using the average linkage clustering within the groups. Data shows 6 clusters representing the different land use types which corroborates with the land use types recognized by the researchers on site. The data suggests that fern density as the species variable used in the cluster analysis was reflective of the field conditions. Distinct fern species dominated certain land use types (Table 4, 5, 6, 7, 8, and 9). 


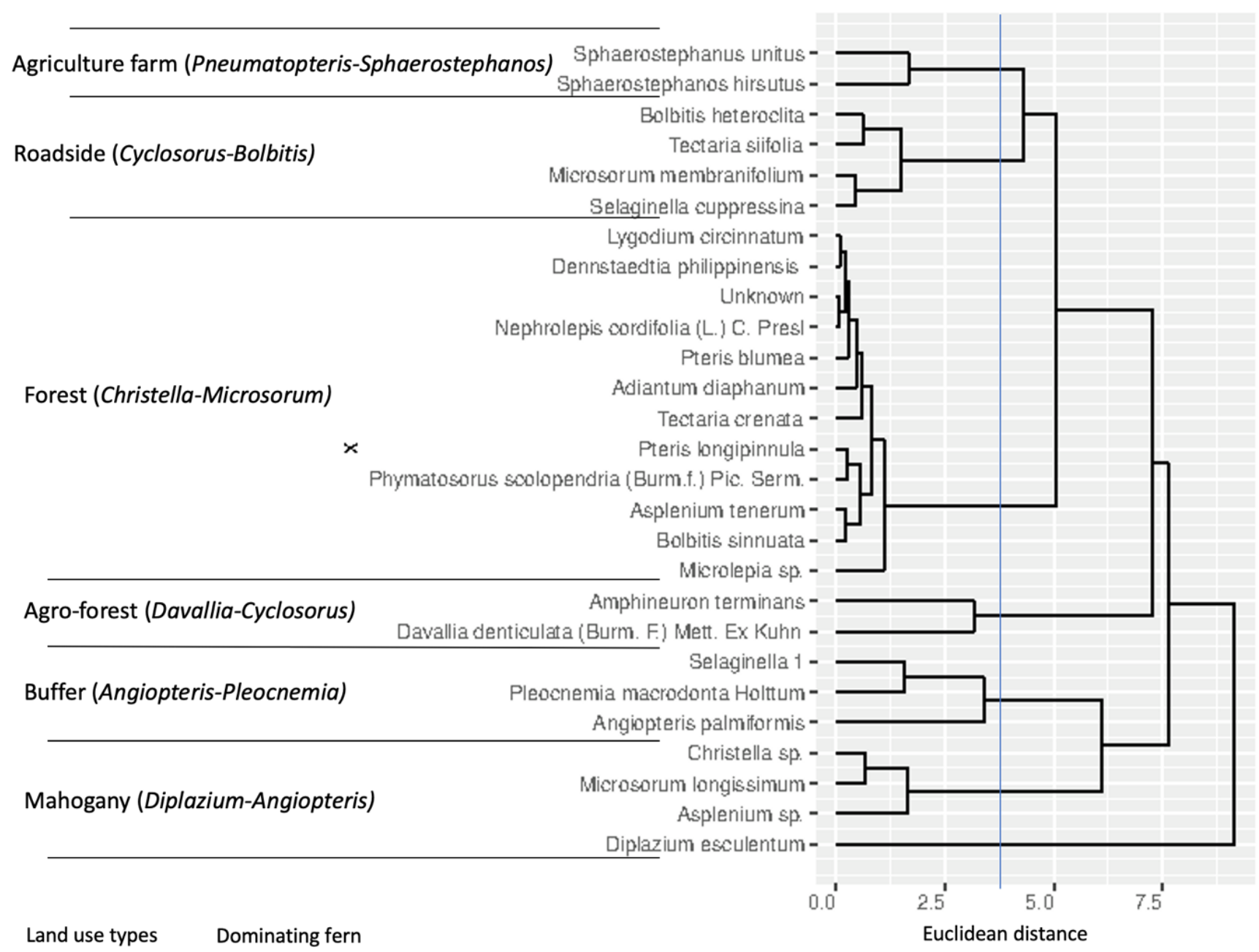

Fig 3. Dendrogram constructed by average linkage within groups using the Euclidean distance resulting to 6 land use types with their respective dominant fern species recorded from 18 plots established at Mt. Makiling Forest Reserve.

\section{Mahogany: Diplazium and Angiopteris Cluster}

The Mahogany land use type (Figure 4) was dominated by Diplazium esculentum (IV=7.5) (Table 4). This land use type is near several household communities. Members of the community may have been cultivating this fern species due to its economic value. Diplazium esculentum locally known as "pako", is considered as a vegetable and enjoyed by many as an additional food source. It is an indigenous edible fern in the Philippines which is abundant in the southern parts of the Island of Luzon reaching up until the central Visayas Region (Tongco et al., 2014). Its fiddleheads are harvested, blanched and served by locals as vegetable dishes or as salads. However, this land use type is recorded to have the lowest number of fern species. It may be due to the limited space for other fern species to grow on and the possible cultivation of select fern species in the area. 


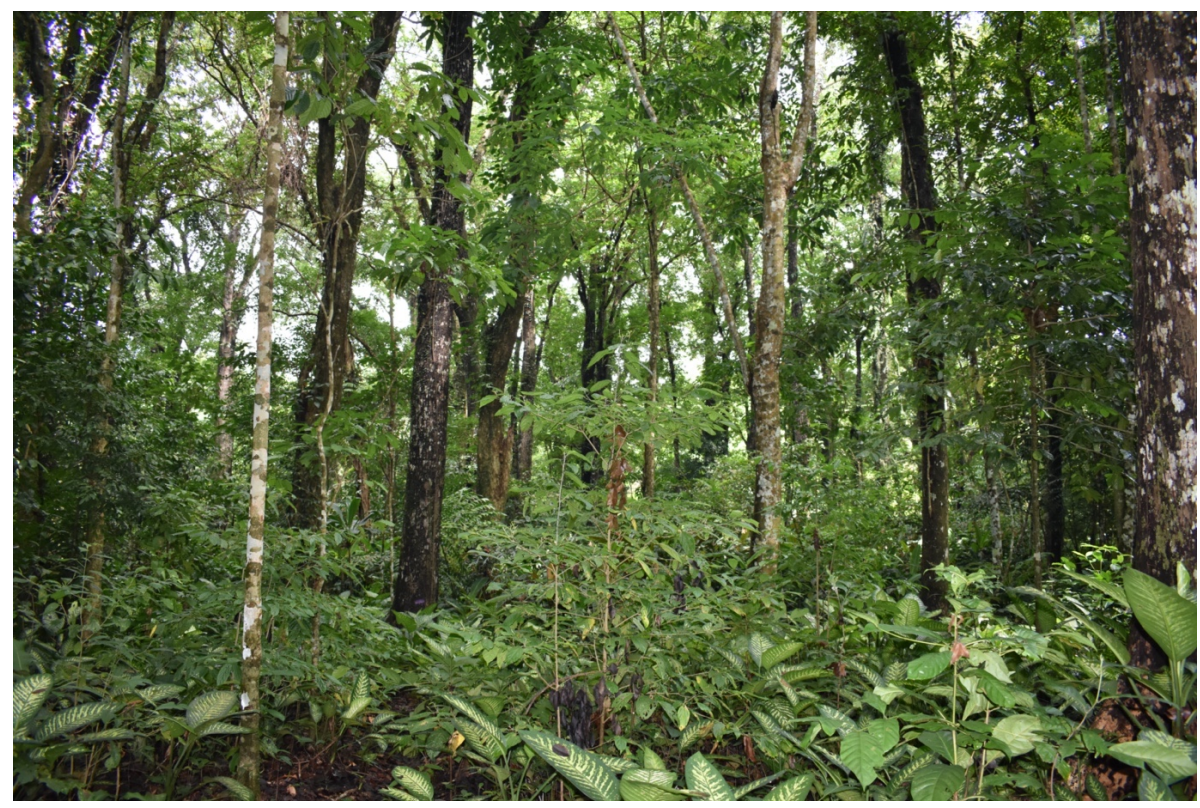

Fig 4. Mahogany land use type in Mt. Makiling Forest Reserve, Philippines.

\section{Buffer: Angiopteris and Pleocnemia Cluster}

Angiopteris evecta is cultivated throughout the tropics (Christenhusz and Toivonen, 2007) and it can be found in Philippine mountain ecosystems. In the Buffer land use type (Figure 5), Angiopteris evecta had the highest importance value of 4.17 (Table 5). Based from the Department of Environment and Natural Resources Administrative Order (DAO) 2017-11, its conservation status is Other Threatened Species and was listed as Angiopteris palmiformis (Cav.) C. Chr. One management strategy in order to conserve this threatened species is to recognize the importance of buffer land use types as a suitable area for its growth and create protocols for its management and conservation. 


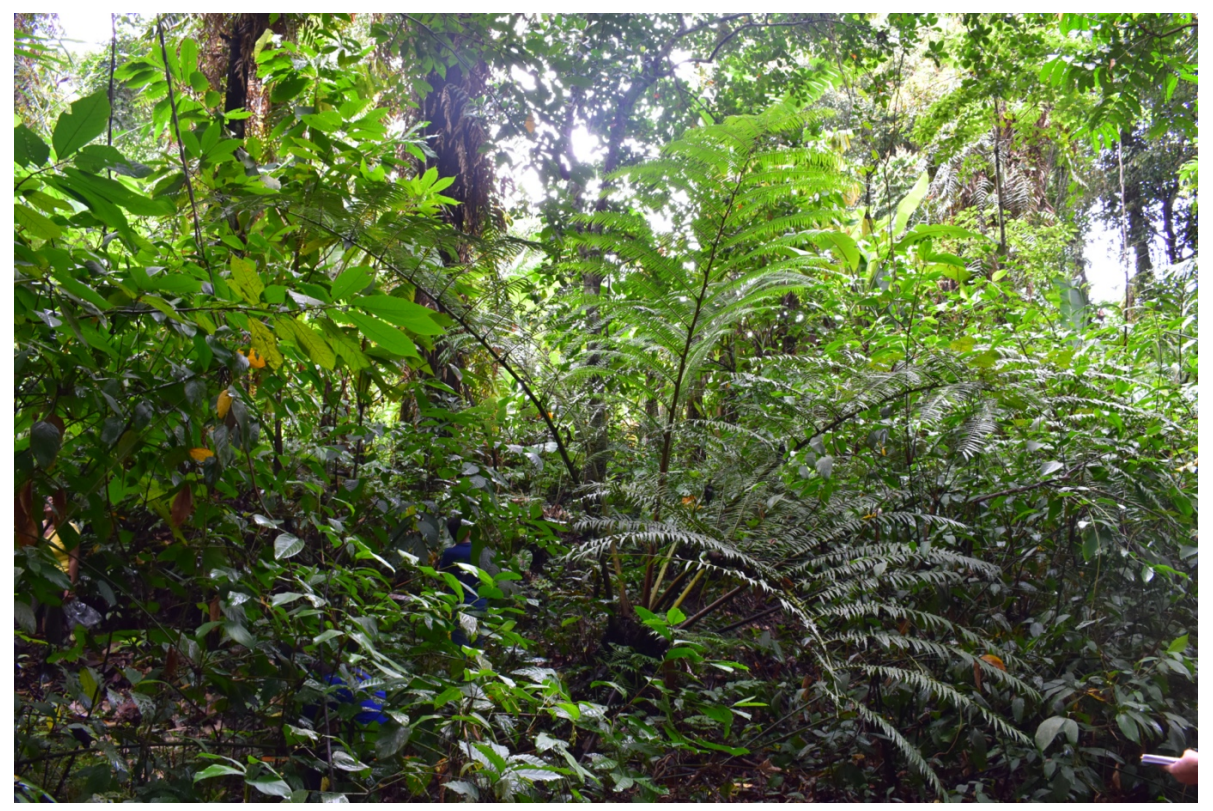

Fig 5. Buffer land use type in Mt. Makiling Forest Reserve, Philippines

Agroforest: Davallia and Cyclosorus Cluster

The agroforest land use type (Figure 6) is comprised of trees and shrubs which are purposely planted in association with economically important crops. This land use type also had a rich species composition which was dominated by the fern species Davallia denticulata (14.44) are Cyclosorus terminans (13.48) (Table 6).

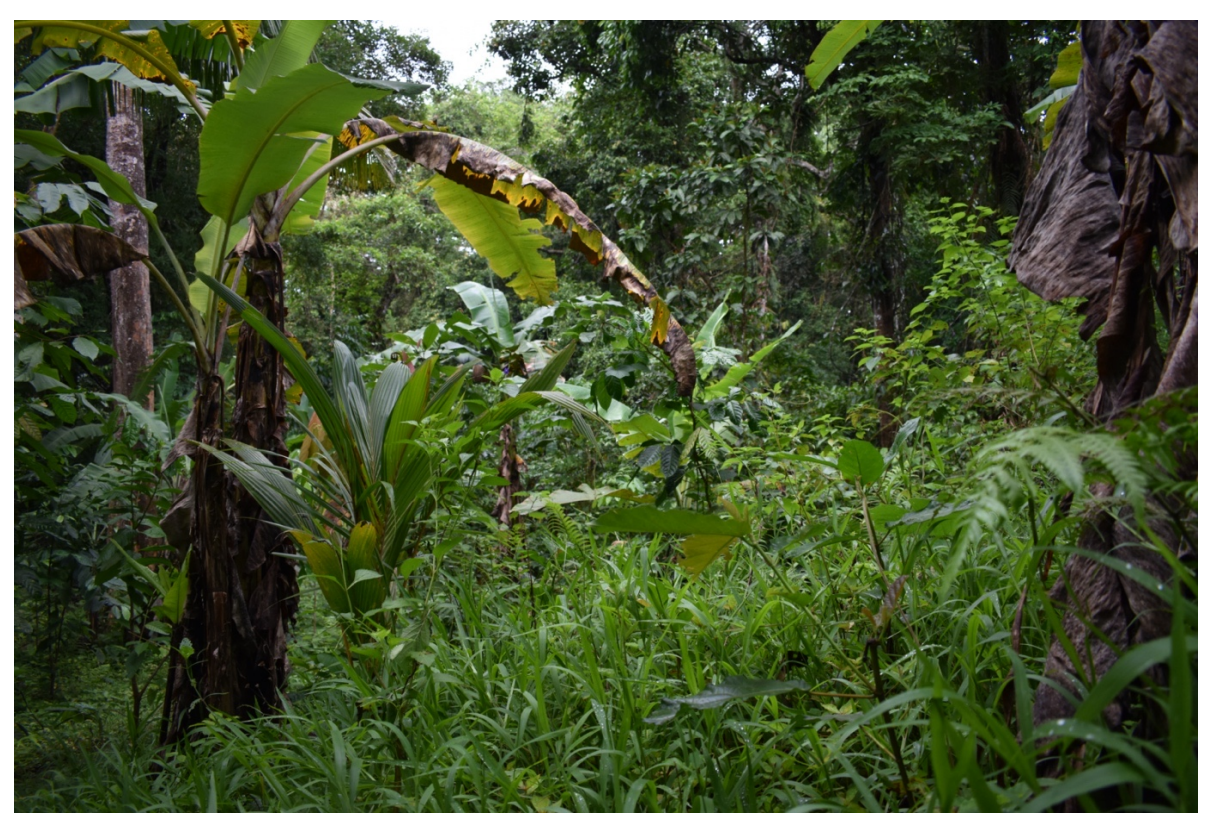

Fig 6. Agroforest land use type in Mt. Makiling Forest Reserve, Philippines. 


\section{Forest: Christella and Microsorum Cluster}

This zone has the highest number of fern species, the dominating ferns species in this land use type are Christella and Microsorum which are members of the family Thelypteridaceae and Polypodiaceae respectively (Table 7). Members of the Thelypteridaceae are terrestrial where some are lithophytic whereas members of the Polypodiaceae are mostly epiphytic and are sometimes terrestrial. Dominance of these fern species as well as the high species richness in this land use type can be attributed to less anthropogenic disturbances and the diversity of trees in the forests (Figure 7) providing a microclimate as well as a variety of substrates that can be favorable for the growth and development of a number of fern species.

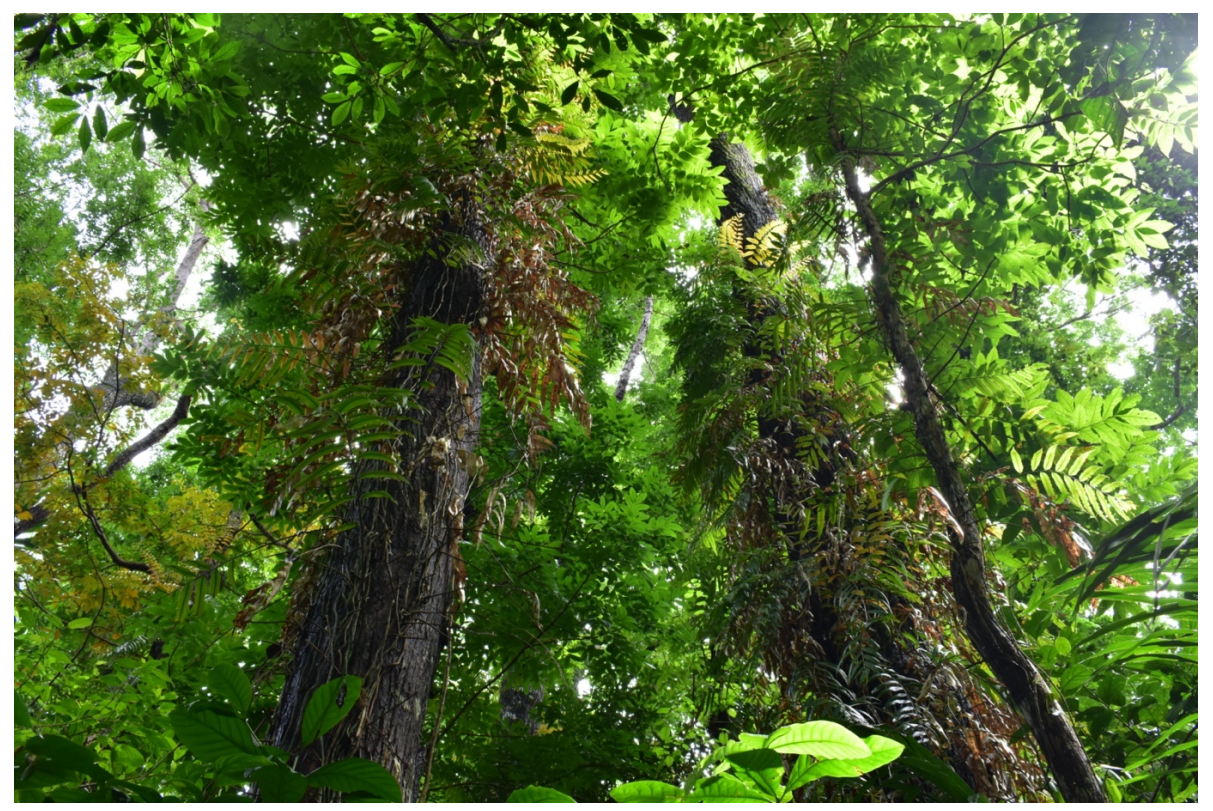

Fig 7. Forest land use type in Mt. Makiling Forest Reserve, Philippines.

\section{Roadside: Cyclosorus and Bolbitis Cluster}

This land use type experiences the highest degree of anthropogenic disturbance since it is found at the wayside of the road (Figure 8). It is frequently being utilized by trekkers and researchers among others to ascend the mountain. Moreover, this land use type has a rocky type of topology and thus lithophytic species are expected to dominate this land use type. The dominant fern species in this land use type, Bolbitis heteroclita (IV=2.55) (Table 8), which are commonly found on rocks or at the base of trees or near streams (Flora of China, 2019). Cyclosorus which is a member of the family Thelypteridaceae are terrestrial whereas some are lithophytic. 


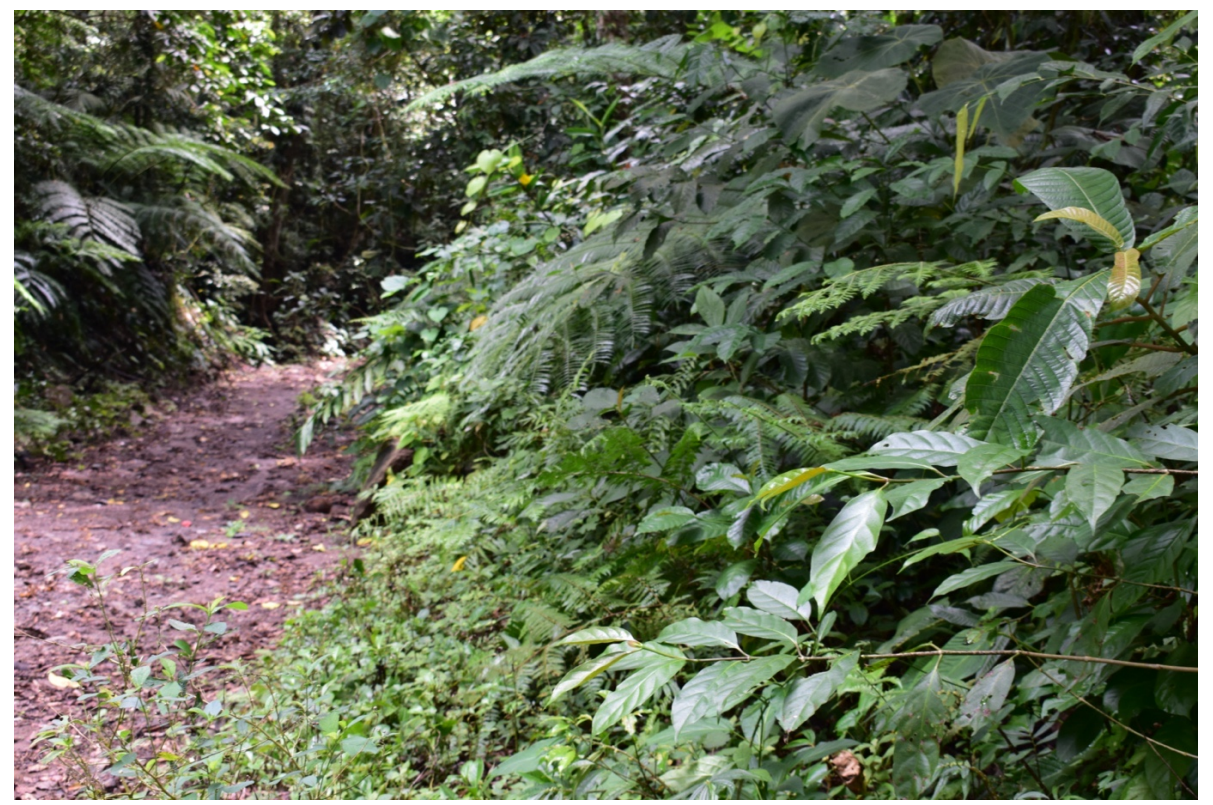

Fig 8. Roadside land use type in Mt. Makiling Forest Reserve, Philippines.

Agrifarm: Pneumatopteris and Sphaerostephanos Cluster

Agrifarm land use types (Figure 9) have access to irrigation and have open areas with clearings for the cultivation of economically important crops. This zone was dominated by the fern species Pneumatopteris nitidula and Sphaerostephanos unitus (Table 9). Both fern species are members of the fern family Thelypteridaceae which is cosmopolitan in distribution and important to fern diversity in tropical forests (Smith et al., 2006). This family is commonly known as the Marsh fern family (Munro, Newell, and Hill, 2014).

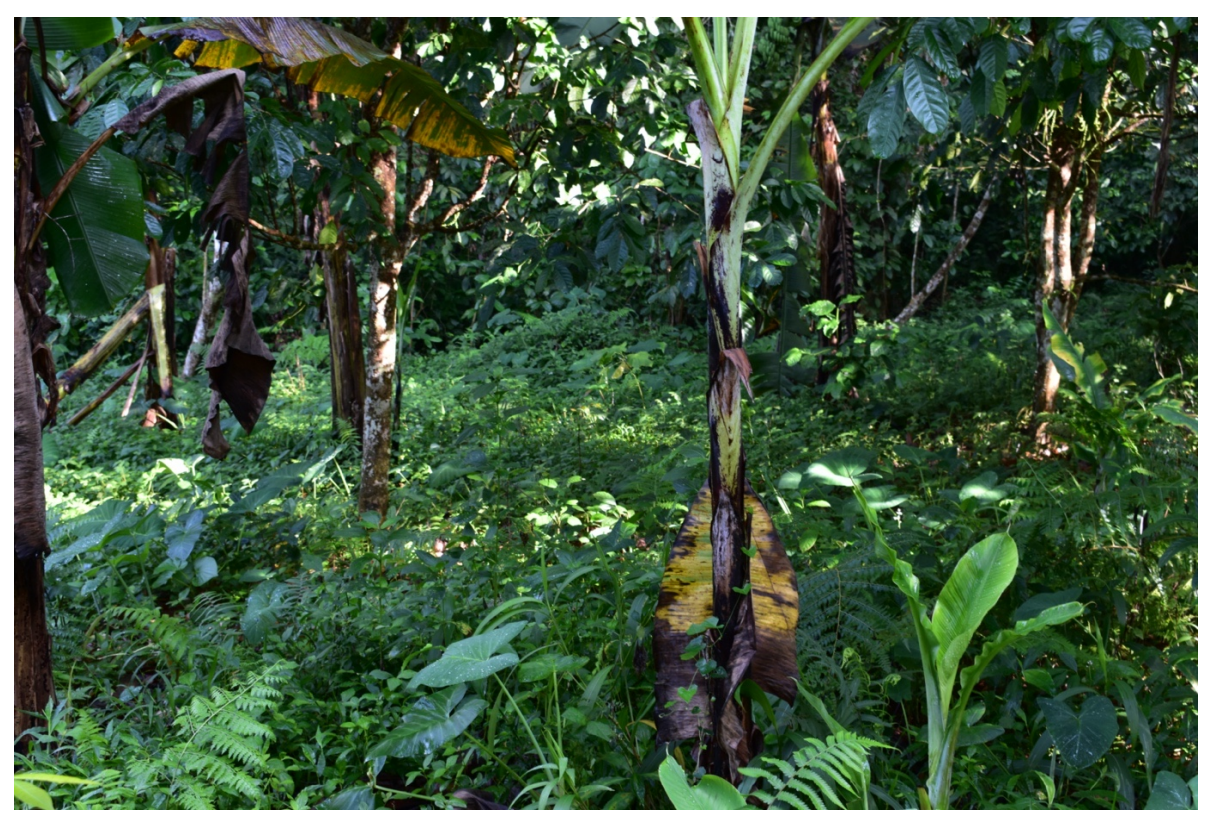

Fig 9. Agrifarm land use type in Mt. Makiling Forest Reserve, Philippines 
Table 4. Importance value and rank of dominant species collected from the Mahogany land use type (341 m.a.s.l.) of Mt. Makiling Forest Reserve.

\begin{tabular}{|l|l|l|l|l|}
\hline \multicolumn{1}{|c|}{ Fern species } & \multicolumn{1}{|c|}{ Relative Frequency (RF) } & \multicolumn{1}{|c|}{ Relative Cover (RC) } & \multicolumn{1}{|c|}{ Importance Value (IV) } & \multicolumn{1}{c|}{ Rank } \\
\hline Diplazium esculentum & 7.021877205 & 8.052337595 & 7.5371074 & 1 \\
\hline Angiopteris palmiformis & 0.423429781 & 1.559523098 & 0.99147644 & 2 \\
\hline Davallia denticulata (Burm. F.) Mett. Ex Kuhn & 0.776287932 & 1.057876501 & 0.917082217 & 3 \\
\hline Pteris longipinnula & 0.811573747 & 0.174146746 & 0.492860247 & 4 \\
\hline Phymatosorus scolopendria(Burm.f.) Pic. Serm. & 0.352858151 & 0.184543567 & 0.268700859 & 5 \\
\hline Asplenium sp. & 0.07057163 & 0.337896671 & 0.204234151 & 6 \\
\hline
\end{tabular}

Table 5. Importance value and rank of dominant species collected from the Buffer land use type (365 m.a.s.l.) of Mt. Makiling Forest Reserve.

\begin{tabular}{|l|l|l|l|l|}
\hline \multicolumn{1}{|c|}{ Fern species } & \multicolumn{1}{|c|}{ Relative Frequency (RF) } & \multicolumn{1}{|c|}{ Relative Cover (RC) } & \multicolumn{1}{|c|}{ Importance Value (IV) } & \multicolumn{1}{|c|}{ Rank } \\
\hline Angiopteris evecta & 1.517290049 & 6.829411566 & 4.173350808 & 1 \\
\hline Pleocnemia macrodontaHolttum & 2.646436133 & 3.217815992 & 2.932126062 \\
\hline Selaginella 1 & 3.563867325 & 0.4028768 & 1.983372063 & 2 \\
\hline Tectaria crenata & 0.282286521 & 0.72517824 & 0.503732381 & 4 \\
\hline Diplazium esculentum & 0.458715596 & 0.447063288 & 0.452889442 & 5 \\
\hline Bolbitis sinnuata & 0.105857445 & 0.270317337 & 0.188087391 & 6 \\
\hline Pteris blumea & 0.317572336 & 0.049384898 & 0.183478617 \\
\hline Pteris longipinnula & 0.247000706 & 0.103968207 & 0.175484456 \\
\hline Selaginella cuppressina & 0.176429076 & 0.150753899 & 0.163591487 \\
\hline
\end{tabular}

Table 6. Importance value and rank of dominant species collected from the Agroforestry land use type (368 m.a.s.l.) of Mt. Makiling Forest Reserve.

\begin{tabular}{|l|l|l|l|l|}
\hline \multicolumn{1}{|c|}{ Fern species } & \multicolumn{1}{|c|}{ Relative Frequency (RF) } & \multicolumn{1}{|c|}{ Relative Cover (RC) } & \multicolumn{1}{c|}{ Importance Value (IV) } & \multicolumn{1}{c|}{ Rank } \\
\hline Davallia denticulata (Burm. F.) Mett. Ex Kuhn & 18.41919548 & 10.46699919 & 14.44309734 & 1 \\
\hline Cyclosorus terminans (J. Sm. Ex Hook.) K.H. Shing & 5.822159492 & 21.12893877 & 13.47554913 & 2 \\
\hline Selaginella 1 & 2.858151023 & 0.275515747 & 1.566833385 & 3 \\
\hline Pleocnemia macrodonta Holttum & 0.599858857 & 0.512043417 & 0.555951137 & 4 \\
\hline Microsorum longissimum & 0.211714891 & 0.857737704 & 0.534726297 & 5 \\
\hline Dennstaedtia philippinensis & 0.494001411 & 0.337896671 & 0.415949041 & 6 \\
\hline Microlepia sp. & 0.247000706 & 0.374285543 & 0.310643125 \\
\hline Diplazium esculentum & 0.14114326 & 0.319702235 & 0.230422748 & 7 \\
\hline Tectaria siifolia & 0.14114326 & 0.285912568 & 0.213527914 & 8 \\
\hline Lygodium circinnatum & 0.105857445 & 0.07537695 & 0.090617198 \\
\hline
\end{tabular}


Table 7. Importance value and rank of dominant species collected from the Forest land use type (482 m.a.s.l.) of Mt. Makiling Forest Reserve.

\begin{tabular}{|l|l|l|l|l|}
\hline \multicolumn{1}{|c|}{ Fern species } & \multicolumn{1}{|c|}{ Relative Frequency (RF) } & \multicolumn{1}{c|}{ Relative Cover (RC) } & \multicolumn{1}{|c|}{ Importance Value (IV) } & \multicolumn{1}{|c|}{ Rank } \\
\hline Christella sp. & 4.516584333 & 5.551902228 & 5.034243281 & 1 \\
\hline Microsorum longissimum & 8.115737474 & 1.715475408 & 4.915606441 & 2 \\
\hline Angiopteris palmiformis & 1.446718419 & 5.058053247 & 3.252385833 & 3 \\
\hline Asplenium sp. & 3.987297107 & 1.806447588 & 2.896872347 & 4 \\
\hline Pleocnemia macrodontaHolttum & 2.858151023 & 1.419166019 & 2.138658521 & 5 \\
\hline Bolbitis sinnuata & 1.940719831 & 0.142956284 & 1.041838057 \\
\hline Asplenium tenerum & 0.741002117 & 0.63420606 & 0.687604088 \\
\hline Phymatosorus scolopendria (Burm.f.) Pic. Serm. & 0.741002117 & 0.184023726 & 0.462512921 & 7 \\
\hline Selaginella 1 & 0.776287932 & 0.119563438 & 0.447925685 \\
\hline Pteris longipinnula & 0.388143966 & 0.24692449 & 0.317534228 \\
\hline Lindsaea fissa & 0.599858857 & 0.025992052 & 0.312925454 & 8 \\
\hline Nephrolepis cordifolia (L.) C. Presl & 0.247000706 & 0.070178539 & 0.158589623 \\
\hline Adiantum diaphanum & 0.07057163 & 0.122162643 & 0.096367136 \\
\hline
\end{tabular}

Table 8. Importance value and rank of dominant species collected from the Roadside land use type (455 m.a.s.l.) of Mt. Makiling Forest Reserve.

\begin{tabular}{|l|l|l|l|l|}
\hline \multicolumn{1}{|c|}{ Fern species } & \multicolumn{1}{|c|}{ Relative Frequency (RF) } & \multicolumn{1}{|c|}{ Relative Cover (RC) } & \multicolumn{1}{c|}{ Importance Value (IV) } & \multicolumn{1}{c|}{ Rank } \\
\hline Cyclosorus terminans (J. Sm. Ex Hook.) K.H. Shing & 3.034580099 & 2.06896731 & 2.551773704 \\
\hline Bolbitis heteroclita & 2.505292872 & 2.378272724 & 2.441782798 \\
\hline Tectaria siifolia & 2.399435427 & 1.51533661 & 1.957386019 \\
\hline Angiopteris evecta & 0.952717008 & 2.674582113 & 1.81364956 \\
\hline Selaginella cuppressina & 2.822865208 & 0.285912568 & 1.554388888 & 3 \\
\hline Sphaerostephanos hirsutus & 0.917431193 & 1.486745353 & 1.202088273 \\
\hline Microsorum membranifolium & 0.917431193 & 1.307400197 & 1.112415695 \\
\hline Pleocnemia macrodonta Holttum & 0.741002117 & 0.55882911 & 6.649915614 & 7 \\
\hline
\end{tabular}

Table 9. Importance value and rank of dominant species collected from the Agri-farm (355 m.a.s.l.) land use type of Mt. Makiling Forest Reserve.

\begin{tabular}{|l|l|l|l|l|}
\hline \multicolumn{1}{|c|}{ Fern species } & \multicolumn{1}{|c|}{ Relative Frequency (RF) } & \multicolumn{1}{|c|}{ Relative Cover (RC) } & \multicolumn{1}{|c|}{ Importance Value (IV) } & \multicolumn{1}{c|}{ Rank } \\
\hline Diplazium esculentum & 5.575158786 & 4.725354986 & 5.150256886 & 1 \\
\hline Sphaerostephanus unitus & 3.38743825 & 3.0774588913 & 3.232448581 & 2 \\
\hline Sphaerostephanos hirsutus & 1.411432604 & 3.184026325 & 2.297729464 & 3 \\
\hline Cyclosorus terminans & 0.635144672 & 0.849940088 & 0.74254238 & 4 \\
\hline Adiantum diaphanum & 0.352858151 & 0.530237853 & 0.441548002 & 5 \\
\hline Pleocnemia macrodonta Holttum & 0.105857445 & 0.062380924 & 0.084119185 & 6 \\
\hline
\end{tabular}




\section{Fern Community Assemblage}

Changes in terms of fern community heterogeneity is accompanied by changes in fern species composition. Interestingly, different land use types were found to share fern communities based on the degree of disturbance whereas other land use types were found to have distinct fern communities (NMDS ordination, Figure 10). Land use types with high disturbances were found to have similar fern communities. Results showed that fern species composition was shared between: i) Agroforest and Roadside (ANOSIM, R global = 0.1111, P > 0.001), and ii) Agroforest and Mahogany (ANOSIM, R global $=0.1481, P>0.001)$. Both the Agroforest and Roadside land use types shared a number of similar fern species (3 fern spp.) (Cyclosorus terminans , Pleocnemia macrodonta Holttum, and Tectaria siifolia). Land use types with minimal degree of disturbances on the other hand also shared fern communities. The Buffer and Forest land use type (ANOSIM, R global = 0.03704, P > 0.001) shared five (5) fern species (Angiopteris evecta, Bolbitis sinnuata, Pleocnemia macrodonta Holttum, Pteris longipinnula, and Selaginella 1). Interestingly, land use types (roadside, agroforest, and mahogany) which were disturbed shared similar fern communities (Figure 3). On the other hand, land use types (Buffer and Forest) who were recognized to have low disturbances also share similar fern communities.

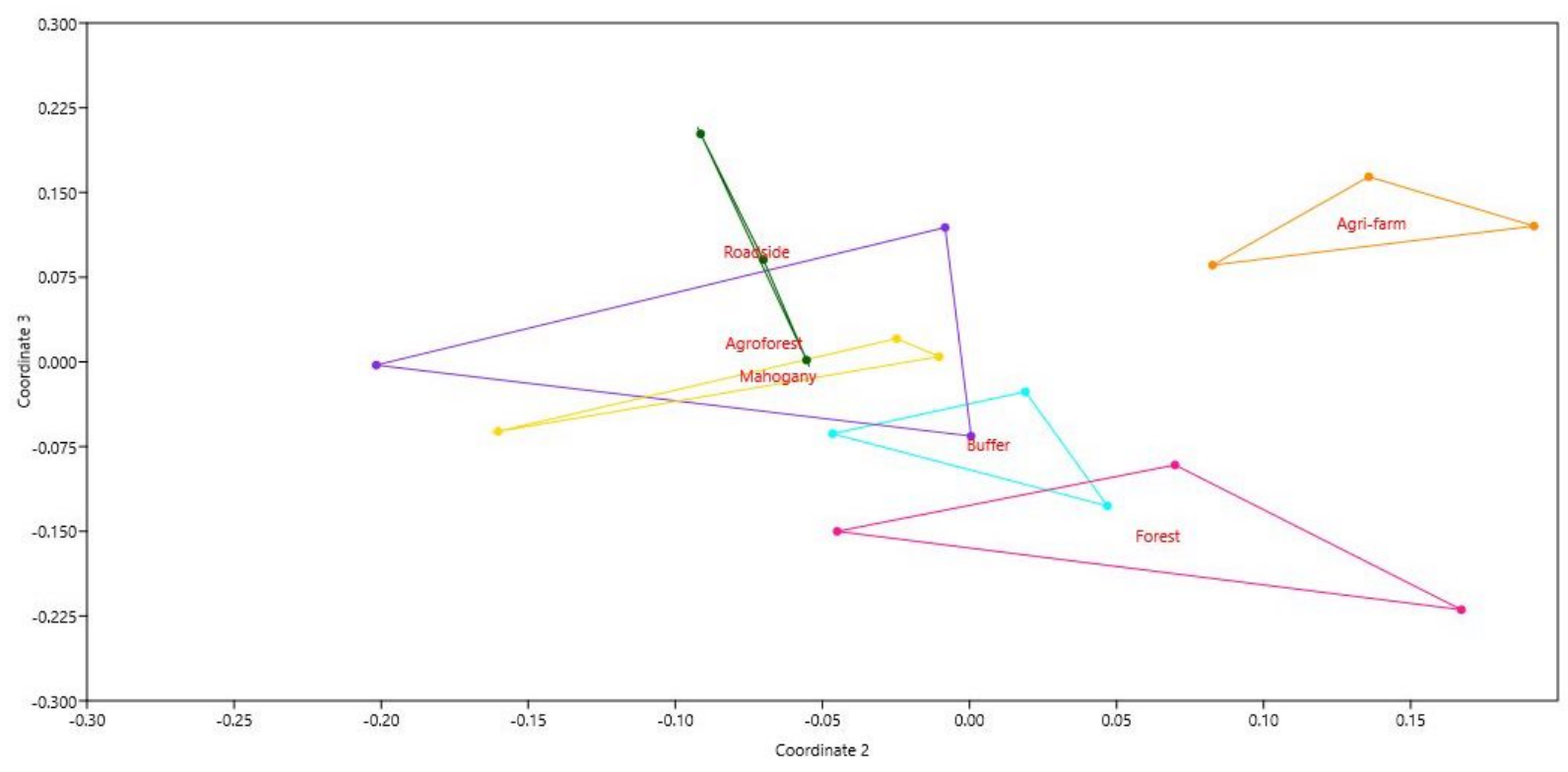

Fig 10. Non-metric Multidimensional Scaling ordination of fern communities recorded from 18 plots across the different land use types of Mt. Makiling Forest Reserve, Philippines. stress value $=0.35$ indicates an adequate fit of the 3-dimensional representation of the distances among land use types.

\section{Edaphic Factors Affecting Fern Communities Across Land Use Types}

All edaphic factors were found correlated based from the resulting CCA with the first two axes explaining ca. 55.71\% of the variation and assemblage patterns among different fern species (Figure 11). High positive correlation was found between moisture and $\mathrm{CEC}$ as well as $\mathrm{pH}$ and $\mathrm{OM}$. These edaphic factors were drivers of fern community assemblage. Fern species richness has often been related to higher humidity and moderate temperature (Kluge et al. 2006). Their effects were found to be more pronounced especially in the Mahogany and Agroforest land use types. 


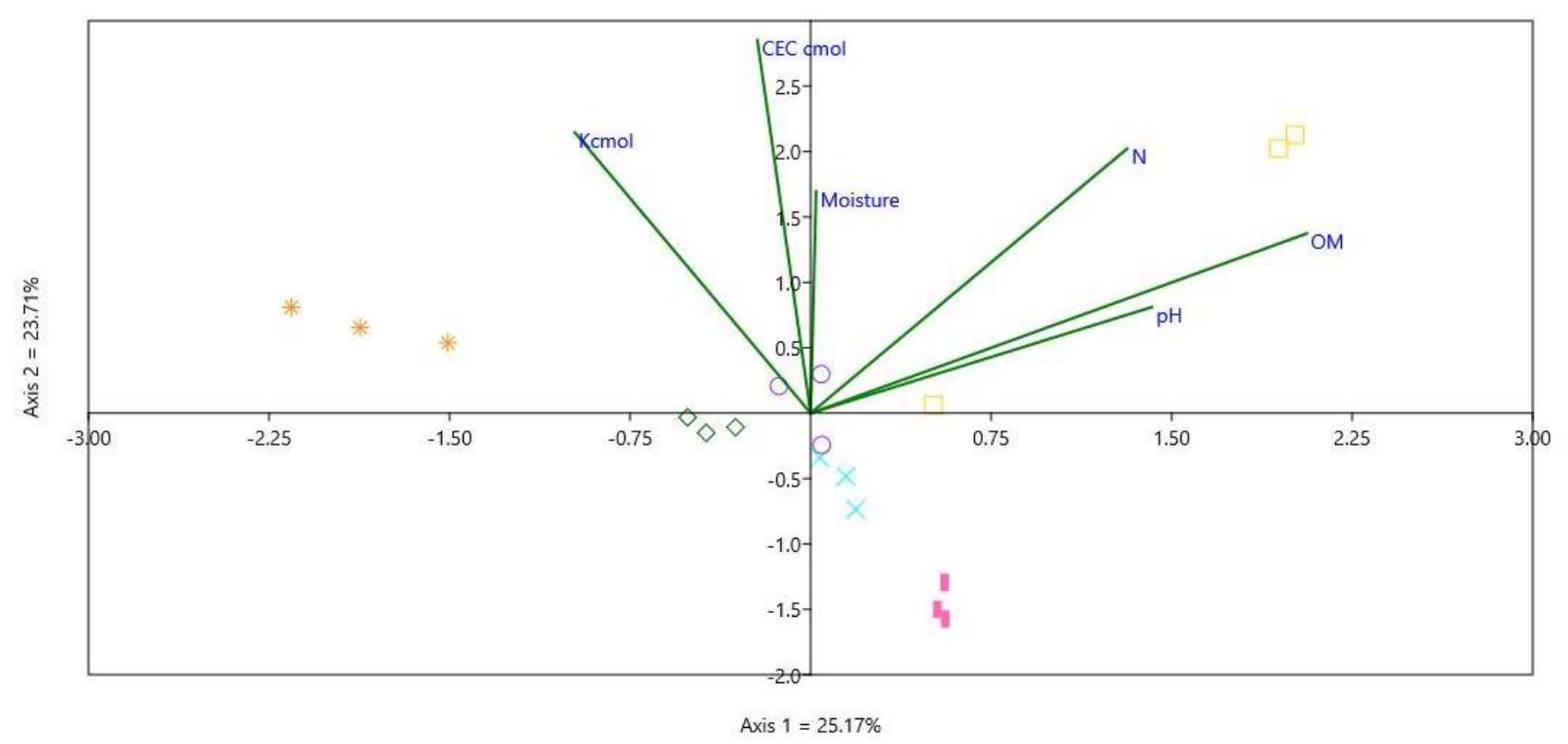

Fig 11. Canonical Correspondence Analysis (CCA) of land use types with edaphic factors recorded across the northeastern slope of Mt. Makiling Forest Reserve.

x: Buffer, $\circ$ : Agroforest, $*$ : Agrifarm, $\diamond$ : Roadside, I : Forest, $\square$ : Mahogany

\section{Notable indicator fern species}

Twelve (12) of the 27 ferns can be considered as indicator species across different land use types. Pteris blumeanaC. Agardh and Tectaria crenata Cav. were found only in buffer zone area. Dennstaedtia philippinensis Copel., Lygodium circinnatum (Burm. f.) Sw. and Microlepia sp., were found only in agroforest area; Diplazium esculentum was found only in the Mahogany land use type; Sphaerostephanos unitus (L.) Holttum found only in agricultural; Bolbitis heteroclita (C. Presl) Ching and Microsorum membranifolium (R. Br.) Ching were found in roadside while Asplenium tenerum G. Forst., Christella sp., Lindsaea fissa Copel. and Nephrolepis cordifolia (L.) C. Presl were restricted to the forest.

Similar studies have investigated the potential of fern species as ecological indicators. According to Silva et al. (2018), members of the filmy fern family Hymenophyllaceae (e.g., Vandenboschia radicans, Didymoglossum reptans) and Cyatheaceae (e.g., Alsophila firma, Cyathea divergens) were mainly restricted to the forest interior of their study sites in the state of Veracruz, Mexico. In a study conducted by Chang, Yoon, and Kim (2009), they found that Pteridium aquilinum from the Myoungbong mine, Republic of Korea area may play an important role as ecological indicators of contaminated areas.

\section{Summary and Conclusion}

A total of 29 fern species belonging to 23 genera from 14 families were recorded across 18 plots from various land use types. The families with greatest species richness were recorded to be Thelypteridaceae (5), Polypodiaceae (3), Dryopteridaceae (3), and Pteridaceae (3). The total fern density values of each fern species were subjected to cluster analysis using Euclidean distance. At a dissimilarity level of 3.75, the dendogram revealed 6 clusters representing the 
different land use: i) Mahogany, ii) Agri-farm, iii) Buffer, iv) Agro-forest, v) Roadside, and vi) Forest. The degree of disturbance influenced the species richness and abundance across different land use types. Species richness was observably highest in the Forest land use type which resulted to a total of thirteen (13) fern species. This may be attributed to the diversity of trees in the forests providing a microclimate that is favorable for growth and development for a number of fern species. The Lowest species richness was from the Mahogany and Agri-farm land use types with a total number of six (6) recorded fern species. Low species richness in the Agri-farm land use type may be attributed to frequent tillage and disturbances of the soil as a result of agricultural practices. Analysis showed that moisture, $\mathrm{OM}, \mathrm{pH}$, and CEC were significant explanatory drivers of fern distribution especially in the Mahogany and Agroforest land use type. We found out that some fern species are indicators of a particular land use type. This particular interesting finding needs further investigation in succeeding studies.

\section{Acknowledgements}

The authors would like to express their sincere gratitude to the UPLB Office of the Vice Chancellor for Research and Extension Basic Research 2018 for financially supporting this study under the UPLB Basic Research Program Number DN 23626. Acknowledgement is also extended to Makiling Center for Mountain Ecosystems for granting access and permit (Permit no: MCME-FWD-0219) to conduct this study at Mt. Makiling Forest Reserve (MMFR).

\section{References}

Abotsi KE, Bose R, Adjossou K, Deblauwe V, Rouhan G, Segla KN, Atsri KH, \& Kokou K., 2020. Ecological drivers of pteridophyte diversity and distribution in Togo (West Africa). Ecol Indic. 108:10571.

Baguinon N, Quimado M, \& Franciso, G., 2005. Country report on forest invasive species in the Philippines. The unwelcome guests. Online march 11, 2020. Retrieved from http://www.fao.org/3/ae944e09.htm.

Banaticla, M.C.N., Buot, I.E., JR., 2004. Fern patch structure and species diversity along the altitudinal gradient on Mount Banahaw de Lucban, Luzon Island, Philippines. Phil. Agric. Scient. 87: 49-60.

Banaticla, M.C.N., Buot, I.E., JR., 2005.Altitudinal zonation of pteridophytes on Mount Banahaw de Lucban, Luzon Island, Philippines. Plant Ecol. 180: 135-151.

Bantayan, NC., 2001. Geomatics-assisted impact assessment of land use change on the biodiversity of the Makiling, Philippines. In: Proceedings of the $22^{\text {nd }}$ Asian Conference on Remote Sensing. Singapore. 5-9 November.

Chang, JS, Yoon, IH, \& Kim, KW., 2009. Heavy metal and arsenic accumulating fern species as potential ecological indicators in Ascontaminated abandoned mines. Ecol Indic. 9: 1275-1279.

Christenhusz, MJM and Toivonen, TK., 2007. Giants invading the tropics: the oriental vessel fern, Angiopteris evecta(Marattiaceae). Biol Invasions. 10(8): 1215-1228.

Clarke, KR and Gorley, RN., 2006. PRIMER v6: User Manual/Tutorial. PRIMER-E, Plymouth.

Claveria, RJR, Perez, TR, Apuan, MJB, Apuan, DA, \& Perez, REC., 2019. Pteris melanocaulon Fee is an As Hyperaccumulator. Chemosphere, 236. Department of Environment and Natural Resources Administrative Order (DAO)., 2017-11. Updated National List of Threatened Philippine Plants and Their Categories

delos Angeles MD and Buot, IE, Jr., 2012. Orders and Families of Philippine Pteridophytes Journal of Nature Studies, 11:19-33. 
delos Angeles, MD, and Buot, IE Jr., 2015. Diversity and Distribution of Pteridophytes along the Altitudinal Gradient of the Northeastern Slope of a Secondary Forest in Mt. Makiling, Philippines. International Journal of Ecology and Conservation. Vol. 16: 25-46.

Fernando, E.S., Sun, B.Y., Suh, M.H., Kong, H.Y., \& Koh, K.S., 2004. Flowering Plants and Ferns of Mt. Makiling. ASEAN-Korea Environmental Cooperation Unit. $368 \mathrm{pp}$.

Flora of China. 2019. Bolbitis heteroclita (C. Presl) Ching in C. Christensen, Index Filic., Suppl. 3: 48., 1934. Online March 13, 2020. Retrieved from http://www.efloras.org/florataxon.aspx?flora_id=2\&taxon_id=200004757.

Jones MM, Tuomisto H, Clark DB, \& Solivas P., 2006. Effects of mesoscale heterogeneity and dispersal limitation on floristic variation in rain forest ferns. J Ecol 94: 181-195.

Kluge, J., Kessler, M., \& Dunn, RR., 2006. What drives elevational patterns of diversity? A test of geometric constraints, climate and species pool effects for pteridophytes on an elevational gradient in Costa Rica. Global. Ecol. Biogeogr. 15, 358-371.

Laguna Lake Development Authoriyu (LLDA)., 2005. Los Baños-Mt. Makiling Micro-watershed Ecoprofile. Laguna de Bay Environmental Action Planning.

Moody K, Monroe CE, Lubigan RT, \& Paller EC., 1984. Major weeds of the Philippines, University of the Philippines Los Baños, College Laguna.

Mueller-Dombois, D. \& Ellenberg, H., 1974. Aims and Methods of Vegetation Ecology. John Wiley and Sons, New York, pp. 547.

Mukaromah, AS, Purwestri, YA, \& Fuji, Y., 2016. Determination of Alleopathic Potential in Mahogany (Swietenia macrophylla King) Leaf Litter Using Sandwich Method. Indonesian Journal of Biotechnology. Vol 21(2): 93-101.

Munro, MC, Newell, RE, \& Hill, NM., 2014. Books: Nova Scotia Plants: Part 1: Ferns and allies. Online March 13, 2020. Retrieved from https://ojs.library.dal.ca/NSM/article/view/4862/4381.

Pancho, JV., 1983. Vascular Flora of Mount Makiling and Vicinity (Luzon: Philippines), Part 1. Kalikasan, The Philippine Journal of Biology, Suppl 1, Kalikasan Press, Manila

Paleontological Statistics Software Package Version 3.25., 2019.

Pelser, PB, Barcelona, JF, \& Nickrent, DL (eds.)., 2011 onwards. Co's Digital Flora of the Philippines. www.philippineplants.org.

Silva, VL, Mehltreter, K, \& Schmitt, JL., 2018. Ferns as potential ecological indicators of edge effects in two types of Mexican forests. Ecol Indic. Elsevier. 93: 669-676.

Smith, AR, Pryer, KM, Schuettpelz, E, Korall, P, Schneider, H., Wolf, PG., 2006. A Classification for extant ferns. Taxon 55, 705-731.

The Pteridophyte Phylogeny Group., 2016. A community-derived classification for extant lycophytes and ferns. J Syst Evol. Vol 54. Issue 6. Pp 563-603.

Tongco, JVV, Villaber, RAP, Aguda, RM, and Razal, RA., 2014. Nutritional and phytochemical screening, and total phenolic flavonoid content of Diplazium esculentum (Retz.) Sw. from Philippines. J Chem Pharm Res. 6(8): 238-242.

Verburg, PH, Overmars, KP, Huigen, MGA, de Groot, WT, \& Veldkamp, A., 2006. Analysis of the effects of land use change on protected areas in the Philippines. Appl Geogr. 26: 153-173. 